\title{
ANALISIS BENTUK GERAK TARI PUTRI BERIAS DI SANGGAR STUDIO LINGGA KOTA LUBUKLINGGAU
}

\author{
Oleh: \\ Lia Paputri \\ (Guru Seni Budaya SMP Negeri Muara Batang Tebu Muratara)
}

\begin{abstract}
ABSTRAK
Permasalahan dalam penelitian ini adalah "Bagaimana Analisis Bentuk Gerak tari Putri Berias Di Sanggar Studio Kota Lubuklinggau," Tujuannya untuk mengetahui Analisis Bentuk Gerak tari Putri Berias Di Sanggar Studio Kota Lubuklinggau dengan menggunakan Analisis bentuk gerak dalam Kajian Tari Teks dan Konteks Y. Sumandiyo Hadi yang berisi 7 prinsip bentuk. Metode penelitian yang digunakan oleh peneliti adalah metode deskriptif kualitatif Dengan teknik pengumpulan data observasi, wawancara,

dan dokumentasi. Berdasarkan hasil penelitian yang dilakukan dengan menggunakan konsep Y. Sumandiyo Hadi yang berisi 7 prinsip bentuk yaitu kesatuan, variasi, repitisi atau ulangan, transisi atau perpindahan, rangkaian, perbandingan dan klimaks, diketahu bahwa (1) Kesatuan merupakan unsur satu kesatuan dalam tari yakni unsur gerak, ruang, dan waktu. Dalam gerak pasti akan menggunakan tenaga, karena dengan adanya tenaga dalam sebuah gerak tari akan mempermudah penonton untuk memahami maksud dan makna dari apa yang ingin disampaikan penari. (2) Variasi terdapat ragam gerak Pakai Anting kaena melakukan gerakan ukel tangan kedalam dan keluar. (3) Repetisi atau Ulangan terdapat ragam gerak Tabur, Meliuk Penuh, Pakai Bedak, Pakai Alis, Pakai Lipstik, Sisir Rambut atau Gelungke Rambut, Pakai Gelang, dan Pakai Anting. (4) Transisi atau Perpindahan terdapat ragam gerak Meliuk Penuh, Tabur, Dan Ukel Tunduk. (5) Rangkaian pada rrangkaian terdapat ragam gerak keseluruhan dari awal hingga akhir. (6) Perbandingan dalam analisis bentuk gerak tari Putri Berias tidak dibahas atau dilakukan (7) Klimaks terdapat gerakan Meliuk Penuh, Ukel Tunduk, Lenggang Duduk, Pakai Bedak, Pakai Alis, Pakai Lipstik, Sisir Rambut atau Gelungke Rambut dan Sembah Akhir.
\end{abstract}

Kata Kunci: Analisis Bentuk Gerak, Tari Putri Berias

\section{A. PENDAHULUAN}

Kebudayaan adalah keseluruhan yang kompleks meliputi pengetahuan, kepercayaan, kesenian, hukum, moral, adat dan berbagai kemampuan serta kebiasaan yang diperoleh manusia sebagai anggota masyarakat (Tylor Dalam Pujileksono, 2015 : 24). Selain itu kebudayaan merupakan hasil aktivitas manusia yang turun temurun dari generasi kegenerasi yang semakin lama semakin banyak. Menyadari pentingnya arti sebuah kebudayaan, maka kebudayaan harus terus digali dan dilestarikan sesuai dengan kepribadian dan kesenian yang ada di dalam jiwa setiap masyarakat. Seni merupakan sesuatu yang menampilkan keindahan dan menciptakan kebahagian bagi yang melihat maupun mendengar, terdapat beberapa macam seni yaitu: seni rupa, seni musik, seni tari, seni teater dan seni sastra.

Tari tradisional adalah suatu tarian yang pada dasarnya di suatu daerah tertentu yang berpedoman luas dan berpijak pada adaptasi kebiasaan secara turun temurun yang dianut oleh masyarakat dan menjadi budaya masyarakat tersebut, tentunya di Indonesia tari tradisional ada beraneka ragam yang 
merupakan suatu nilai-nilai budaya bangsa Indonesia yang tak ternilai harganya. Oleh karena itu sebagai penerus generasi harus menjaga dan melestarikan tarian tradisional daerah masing-masing khusunya Sumatera Selatan (http://sukasosial.blogspot.com).

Tari Putri Berias merupakan tari tradisional Kota Lubuklinggau. Konon ceritanya di daerah tersebut hiduplah seorang putri yang sangat cantik luar biasa, rambutnya yang panjang terurai, bulu mata yang lentik, mata yang bersinar dan kulit yang halus yang membuat setiap orang melihatnya terkagumkagum, karena selain cantik dan pandai putri ini juga mahir menari, dimana gerakan tari ini pada umumnya gerakan-gerakan yang menggambarkan aktivitas seorang gadis yang sedang berias seperti menyisir rambut, memakai bedak dan lainnya. Dimana dahulu kala tarian ini dikenal dengan tari gunjing yang artinya ialah umpatan atau hinaan. Tarian

gunjingan masyarakat bila tidak memiliki keterampilan. Tarian ini ditarikan dengan jumlah yang ganjil dan dimana setiap gerakannya adalah gerakan-gerakan gadis yang sedang berias yang digerakkan dengan lemah gemulai dan iringan musik yang selaras megikuti gerakan tari. Tari Putri Berias sudah dikenal di masyarakat khususnya Kota Lubuklinggau dan dilestarikan oleh dinas kebudayaan dan parawisata kota Lubuklinggau dan juga sering dipertunjukkan pada acaraacara festival dan acara lainnya, yang dibawa dan dikenalkan oleh sanggar-sanggar yang ada di kota Lubuklinggau terutama Sanggar Studio Lingga yang merupakan salah satu sanggar yang ikut mengeksistensikan tarian ini.

Sanggar Studio Lingga merupakan salah satu sangggar yang ada di Kota Lubuklinggau yang dipimpin oleh Bapak Darwis, S.Pd, M.Si dan dibantu oleh Sapda Priajaya, S.Pd sebagai pelatih tari di Sanggar Studio Lingga. Sanggar Studio Lingga didirikan sejak tahun 2009 yang berawal dari maraknya permintaan untuk menampilkan kesenian daerah yang ada di Lubuklinggau dan sulitnya mencari generasi penerus yang benar-benar bisa mencintai kesenian daerah yang dimiliki, maka timbullah pemikiran seniman muda itu untuk mendirikan suatu wadah yang bisa menampung kreatifitas anak-anak muda untuk menyalurkan bakatnya. Dengan adanya Sanggar Studio Lingga sangat membantu

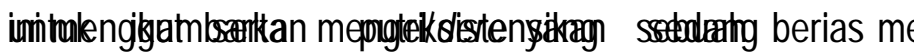
tarian yang ada di Kota Lubuklinggau khususnya tari tradisional yang menjadikan suatu ciri khas dari daerah tersebut.

Tari Putri Berias sering ditampilkan di acara-acara festival dan hari- hari besar, bukan hanya di Kota Lubuklinggau tetapi sudah sering juga ditampilkan di luar Kota dalam rangka mengikuti lomba ataupun undangan mengisi acara tertentu. Tari tersebut gerakannya menggambarkan gadis yang sedang berias, dan merupakan tarian tradisional Kota Lubuklinggau yang mempunyai keunikan gerak dan makna 
tersendiri yang seharusnya sudah dikenal oleh seluruh masyarakat Lubuklinggau terutama generasi penerus, yang tidak hanya mengenal nama tariannya tetapi juga makna dan keunikan tari Putri Berias.

Melihat perkembangan zaman dan banyaknya muncul tarian baru di Indonesia khusunya di daerah Lubuklinggau yang sudah mengenal tari modern dan sejenisnya sehingga membuat lupa akan suatu tarian di daerah sendiri yang seharusnya menjadikan suatu ciri khas dan warisan daerah sendiri yang harus selalu dijaga dan dilestarikan khususnya para generasi muda yang hanya mengenal nama tariannya saja. Tari Putri Berias merupakan salah satu tari tradisional yang ada di Kota Lubuklinggau yang harus dikembangkan dan dikenalkan lebih luas lagi kepada seluruh masyarakat khususnya generasi muda agar tidak punah dan selalu terjaga keberadaannya.

$\mathrm{Hal}$ inilah yang menjadikan penulis tertarik untuk mengangkatnya dalam penelitian tari Putri Berias ini karena ingin mendapatkan dan menambah wawasan secara detail tentang tariannya, karena tari Putri Berias masih sangat eksis di daerah Lubuklinggau serta melihat keunikan gerak yang dimilikinya seperti gerak memakai bedak, memakai kalung dan anting dan gerakan-gerakan lainnya yang menggambarkan seorang gadis sedang mempercantikkan dirinya.

Mengenai hal tersebut dengan meneliti bentuk gerak tari Putri Berias di Sanggar
Studio Lingga Kota Lubuklinggau diharapkan semua penikmat khususnya generasi Kota Lubuklinggau tidak hanya mengenali nama tariannya, tetapi juga diharapkan dapat menarikannya. Tari Putri Berias bagi masyarakat Kota Lubuklinggau memiliki makna dikehidupan masyarakat pendukungnya, jika dilihat dari gerakan-gerakan yang ditampilkan diambil dari gerakan keseharian akan tetapi sudah digayakan (distilir). Berdasarkan uraian di atas peneliti tertarik untuk melakukan penelitian tentang" Analisis Bentuk Gerak Tari Putri Berias Di Sanggar Studio Lingga Kota Lubuklinggau".

\section{B. METODE PENELITIAN}

Metode penelitian secara umum diartikan sebagai cara ilmiah untuk mendapatkan data dengan tujuan dan kegiatan dan kegunaan tertentu (Sugiyono, 2013:3). Penelitian kualitatif adalah suatu prosedur penelitian yang menghasilkan data deskriptif berupa kata-kata tertulis atau lisan dari orangorang dan perilaku yang dapat diamati (Zuriah, 2005: 92).

Penelitian kualitatif deskriptif merupakan penelitian yang menggungkap fakta, keadaan, fenomena, variabel, dan keadaan yang terjadi saat penelitian berjalan. Penelitian tentang Analisis Gerak Tari Putri Berias menggunakan metode penelitian deskriptif kualitatif karena peneliti mengamati objek yang diteliti serta menentukan bagian mana 
yang akan dianalisis sehingga data yang diperoleh merupakan data yang akurat dan dapat dipercaya.

\section{PEMBAHASAN DAN HASIL PENELITIAN}

Penelitian ini bertujuan untuk mengetahui bentuk gerak Tari Putri Berias di Sanggar Studio Lingga Kota Lubuklinggau. Data dikumpulkan melalui observasi, wawancara, dan dokumentasi. Dari data yang telah dipaparkan di atas dapat diketahui bahwa Tar Putri Berias merupakan Tari Tradisonal Kota Lubuklinggau, tari ini mengandung makna bagaimana seorang gadis menyiapkan diri dengan kepandaian serta keterampilan untuk nantinya sebagai bekal di masyarakat dan juga jangan sampai menjadi gunjingan, yang artinya ialah umpatan atau buah bibir, umpatan yang dimaksud bukan bermaksud umpatan yang tidak bagus tetapi sebaliknya umpatan disini merupakan perkataan yang bagus karena setiap warga menyampaikan dengan warga yang lain, bahwa disatu daerah itu ada seorang putri yang sangat cantik dan pandai menari, dari perkataan satu warga maka sampailah ke telinga warga yang lain bahkan sudah tersebar ke mana-mana dan menjadi bahan umpatan setiap warga dan membuat penasaran bagi yang mengetahuinya.

Tari Putri Berias ditarikan oleh 5 orang penari perempuan yang berperan sebagai para gadis yang sedang berdandan. Tari Putri Berias diteruskan oleh pelatih tari di Sanggar
Studio Lingga yaitu Sapda Jaya, S.Pd dan juga selalu dikembangkan dan selalu dijaga oleh pemerintah kebudayaan agar tetap selalu terjaga dan selalu dikenal oleh masyarakat Lubuklinggau khususnya para generasi, yang belum mengetahui makna yang terdapat dalam tarian ini. Di dalam tari ini sebagaimana diketahui bahwa pencipta tari tidak terlepas dari beberapa unsur yang menyertai, salah satunya ialah unsur bentuk gerak. Gerak dalam suatu tarian merupakan suatu unsur yang melibatkan anggota badan sehingga bisa mengkomunikasikan maksud tertentu yang ingin disampaikan dimana wujud tari yang dinikmati dan dirasakan oleh panca indera yang tidak bisa dipisahkan oleh gerak, ruang, dan waktu.

Bentuk gerak adalah salah satu wujud yang ditampilkan dalam sebuah tari dan memiliki peranan yang sangat penting dalam tarian, karena tanpa adanya bentuk gerak, tari tidak akan tercipta dengan baik. Penulis menggunakan analisis bentuk gerak dalam kajian Tari Teks Dan Konteks Y. Sumandiyo Hadi yang berisi 7 prinsip bentuk gerak yaitu (a) Kesatuan, (b) Variasi, (c) Repetisi atau ulangan, (d) Transisi atau perpindahan, (e) Rangkaian, (f) Perbandingan, (g) Klimaks. Berdasarkan 7 prinsip tersebut maka dapat dimengerti dan memahami tentang analisis bentuk gerak Tari Putri Berias yang terdiri dari berbagai macam ragam gerak.

\section{a) Kesatuan}

Kesatuan adalah prinsip yang sangat 
penting dalam bentuk gerak atau koreografi. "Kesatuan" mengandung pengertian menjadi satu yang utuh. Kesatuan aspek-aspek gerak, ruang, dan waktu yang hadir dalam tari merupakan keutuhan yang siap dihayati dan dimengerti (Hadi, 2007: 25). Kesatuan merupakan unsur konstruksional yang menyeluruh. Wujud akhir yang muncul bila tari telah selesai yaitu melalui kesatuan atau unity, untuk membuat analogi rangkaian bagian- bagian cocok masuk dalam kerangka, maka hasil menjadi keseluruhan gambargambar yang tertata tepat sesuai dengan kerangka yang seharusnya (Smith terjemahan Suharto, 1985: 75-76). Kesatuan adalah kesatuan gerak, ruang, dan waktu. Unsur kesatuan didalam sebuah tari mesti diperlihatkan karena unsur tersebuat merupakan satu kesatuan yang utuh yang akan menghasilkan suatu wujud tarian yang baik dan keseluruhan dalam arti sebenarnya

Gerak adalah sebuah tata hubungan aksi, dan ruang dimana tidak satupun dari aspek tersebut dapat hadir tanpa yang lain dalam motif, tetapi satu atau lebih dapat mendapatkan penekaan dari lainnya. Penata tari dapat memberikan tekanan yang sama pada setiap aspek terutama dalam kaitannya dengan isi gerak motifnya (Smith terjemahan Suharto, 1985: 43-44).

Gerak adalah dasar ekspresi, oleh sebab itu gerak kita temui sebagai ekspresi dari semua pengalaman emosional yang diekspresikan lewat medium yang tidak rasional, yakni gerakan tubuh atau ebahing sadaya sarandhuning badhan gerakan seluruh tubuh (Hadi, 2007: 25)

Gerak dalam suatu tarian merupakan suatu unsur yang melibatkan anggota badan sehingga bisa mengomunikasikan maksud tertentu kepada penonton yang didalamnya memiliki isi, arti, dan makna yang jelas. Didalam suatu tari juga sangat memerlukan tenaga untuk mewujudkan suatu gerak yang memiliki arti.

\section{1) Unsur Tenaga}

Tenaga dalam sebuah tarian sangat penting karena kekuatan yang disalurkan dari seluruh tubuh untuk melahirkan adanya gerak tari, gerak yang muncul dari pengaturan tenaga yang di sampaikan melalui ekspresi sehingga dapat membedakan karakter gerak tari. Tenaga dapat diatur oleh penari untuk mewujudkan kesan atau maksud yang ingin disampaikan oleh penari. Pengaturan tenaga dalam gerak meliputi :

1) Intensitas, merupakan banyak sedikitnya tenaga yang digunakan dalam melakukan gerak tari (www.mikirbae.com). Intensitas dalam Tari Putri Berias dapat dilihat pada saat penari melakukan gerakan meliuk Penuh. Gerakan meliuk Penuh dapat dikatakan gerakan memutar dengan meliuk penuh menggunakan selendang karena dalam gerakan ini penari melakukan gerakan ukel kedua tangan dengan memegang ujung selendang sembari memutar badan (meliuk). Gerakan ini diawali dengan gerakan 
cepat memutar, lalu dibalas dengan memutar gerakan yang mengalun. Dimana gerakan tersebut memerlukan intensitas tenaga untuk melakukannya. Makna gerakan ini yaitu sebagai penghubung gerak dari satu ke gerak selanjutnya.

2) Aksen atau tekanan, yakni penggunaan tenaga yang tidak merata atau gerakan yang dilakukan secara tiba-tiba (www.mikirbae.com). Aksen dalam tari Putri Berias dilihat pada saat penari melakukan gerak lenggang duduk, yang diaplikasikan dengan bentuk gerak kedua tangan seperti terbang sembari duduk. Gerakan ini diartikan sebagai gerakan bersiap untuk gerakan selanjutnya yang melakukan gerakan Berias.

\section{Kualitas}

Kualitas merupakan cara bagaimana tenaga disalurkan untuk menghasilkan gerak (www.mikirbae.com). Dalam tari Putri Berias, penyaluran tenaga terdapat pada ragam gerak pakai kain. Gerakan pakai kain dapat diartikan gerak sedang memakai kain dilihat dari kaki kanan kedepan dijinjit, tangan kanan menarik dari kaki kanan keatas samapai pinggang, lalu di kedua tangan diturunkan kebawah. Penyaluran tenaga dalam gerak tari Putri Berias yaitu pada tumpuhan atau jinjitan kaki kanan kedepan dan tangan kanan menarik dari bawah sampai atas pinggang, serta diikuti dengan kaki kiri dan tangan kiri.

\section{2) Unsur Ruang}

Pamadhi dkk, (2008:2.37) ruang sebagai unsur tari terbagi menjadi 2 yakni ruang yang diciptakan oleh penari dan ruang pentas atau ruang tempat penari melakukan gerak. Ruang adalah suatu usur pokok tari yang menentukan terwujudnya atau terungkapnya gerak, kerena sangat mustahil suatu gerak lahir tanpa adanya ruang gerak. Unsur ruang secara umum diartikan kedalam dua unsur yakni ruang yang diciptakan oleh penari dan ruang pentas atau tempat penari melakukan gerak. Ruang yang diciptakan oleh penari adalah ruang yang dibatasi oleh imajinasi penari yang berupa gerak terjauh dan dapat dijangkau oleh tangan dan kakinya dalam posisi tidak berpindah tempat (Pamadhi, dkk, 2008: 2. 38). Lebar sempitnya ruang yang digunakan untuk melakukan gerak tersebut di atas tergantung bagaimana penari mengekspresikan geraknya, karena pada dasarnya kebutuhan akan ruang itu merupakan bagian tak terpisahkan dengan karateristik tarinya.

Ruang sebagai tempat pentas yaitu tempat penari dalam melakukan gerakan sebagai wujud ruang secara nyata dan merupakan arena yang dilalui penari saat menari. Penjelasan ruang disini dapat berupa panggung proscenium atau tempat pertunjukan lain misalnya panggung, lapangan atau halaman terbuka. Tari Putri Berias dapat ditarikan di halaman terbuka atau di panggung proscenium dan lainnya. 
Dalam Tari Putri Berias gerak yang terhubung dengan unsur ruang misalnya Sembah Duduk, Pakai Kain dan Lenggang Duduk. Gerak Sembah Duduk yaitu gerak satukan pergelangan tangan kedepan, kemudian bentangkan tangan seperti terbang, lalu ayunkan kebawah sembari menyatukan kedua telapak tangan didepan dada dengan posisi duduk. Gerak Pakai Kain yaitu kaki kanan kedepan dijinjit, tangan kanan menarik dari kaki kanan keatas samapai pinggang, lalu di kedua tangan diturunkan kebawah. Gerak Lenggang Duduk yaitu kedua pergelangan tangan ditemukan, lalu bentangkan seperti terbang dengan mengayunkan kedua tangan disamping sembari mengambil posisi duduk.

\section{3) Unsur waktu}

Gerak, frase, dan seksi membentuk pola waktu yang menjadi aspek ritme tari. Dengan begitu setiap gerak mempunyai ritme. Tenaga yang menjadi pangkal gerak terus berjalan dan berhenti, sehingga memberikan wujud dengan penerapan dan pengendoran tenaga selama panjang waktu tari yang dibutuhkan (Smith terjemahan Suharto,1985:61). Unsur waktu dalam tarian ini ada dua faktor yang sangat penting yaitu ritme dan tempo. Ritme merupakan pengaturan waktu dalam melakukan gerak sesuai irama tertentu atau lebih mengarah kepada hitungan ukuran cepat atau lambatnya setiap gerakan yang dapat diselesaikan oleh penari. Sedangkan Tempo merupakan ukuran waktu yang dipergunakan dalam melakukan suatu gerak tari atau lebih mengarah pada kecepatan tubuh penari yang dilihat dari perbedaan panjang dan pendek waktu yang diperlukan. Di dalam Tari Putri Berias ragam gerak yang memiliki tempo cepat yaitu Meliuk Penuh dan Sisir Rambut Atau Gelungke Rambut, sedangkan dengan tempo lambat yaitu gerak Tabur.

\section{b) Variasi}

Variasi merupkan prinsip bentuk yang harus ada dalam sebuah tarian atau koreografi; sebagai karya kreatif harus memahami yang serba "baru". Dalam proses gerak pembentukan gerak, perlu memperlihatkan nilainilai kebaruan itu (Hadi, 2007: 26). Variasi ialah memberikan kemungkinan peningkatan bahwa isi yang telah ditetapkan dalam tari digunakan lagi dalam cara yang berbeda. Kontras mengandung kemungkinan perubahan yang memikat yang mewarnai tari dan berada di luar sebagai titik acuan dalam hubungan dengan isi materi keseluruhan (Smith terjemahan Suharto, 1985: 69). Variasi merupakan suatu pengembangan gerak yang dilakukan untuk bentuk gerak tari yang baru dengan tetap menjaga keutuhan gerak tari yang sudah ada. Pengembangan Variasi pada Tari Putri Berias dilakukan agar penonton merasakan ada variasi gerak dan tidak membosankan.

\section{c) Repetisi atau Ulangan}

Repetisi atau Ulangan dalam bentuk 
gerak tari, nampaknya selalu menghendaki adanya prinsip ulangan karena sifat tari yang terjadi dalam waktu yang sesaat. Tanpa adanya "pengulangan", suatu tangkapan indrawi penglihatan akan cepat hilang, karena berganti dengan tangkapan gerak yang lain (Hadi, 2007:26). Pengulangan merupakan konteks tari sebagai bentuk seni yang mempunyai pengertian lebih luas dari pada penggunaan kata "pengulangan" seperti pada bahasa sehari-hari (Smith terjemahan Suharto, 1985: 69). Dengan menggunakan repetisi atau ulangan maka setiap gerak tari yang ditampilkan tidak cepat hilang dan penonton dapat merangkai setiap bentuk gerak tari dan bisa mengetahui makna yang terdapat dalam Tari Putri Berias.

\section{d) Transisi atau Perpindahan}

Transisi atau Perpindahan merupakan motif gerak transisi yang tidak dapat berdiri sendiri, tetapi harus menyatu dalam kesatuan motif-motif gerak yang akan disambung. Transisi memberikan tenaga hidup dari bentuk gerak sebelumnya, dan berfungsi sebagai pengenalan pindah ke bentuk gerak berikutnya, sehingga bentuk kesatuan itu nampak utuh dan menegaskan (Hadi, 2007: 27). Transisi atau Perpindahan merupakan suatu sambungan gerak, yang berfungsi untuk menyatukan dari gerak satu kegerak selanjutnya dan menjadi penghubung gerak sehingga membentuk satu kesatuan rangkaian dari keseluruhan bentuk gerak agar sebuah tarian tidak terlihat terputusputus atau hilang.

\section{e) Rangkaian}

Rangkaian adalah salah satu prinsip yang perlu diperhatikan karena bentuk gerak tari dapat dirasakan sebagai satu pengalaman, dan bagian-bagian dari bentuk gerak yang akan dirangkai atau disusun harus disimpulkan bersama, sehingga dapat mencapai hubungan satu dengan lainnya (Hadi, 2007: 28). Rangkaian digunakan untuk untuk mengetahui susunan gerak tari dari awal hingga akhir, sehingga tari yang dilakukan menjadi terstruktur dan Tari Putri Berias dapat dipahami dengan mudah.

\section{f) Klimaks}

Klimaks merupakan susunan atau urutan-urutan rangkaian kejadian harus membentuk satu klimaks, agar maksud dari bentuk gerak tercapai. Dalam sebuah tarian atau koreografi selalu ada permulaan, "berjalan" atau "berkembang", dan ada "penyelesaian". "Klimaks" dinikmati sebagai titik puncak dari perkembangan, serta memberi arti dari kehadiran "permulaan", "perkembangan", dan akhir atau "penyelesaian" ( Hadi, 2007: 2829). Klimaks dapat dilihat sebagai akhir pengembangan motif disegala kejadian, bila betul-betul menginginkan untuk mencapai klimaks, maka klimaks harus nampak menonjol. Klimaks tampil seperti percikan bunga api, dan terjadi melalui penuangan pameran artistik, 
keterampilan dan keindahan idea susunan gerak penata tari yang terbentuk sedemikian rupa sehingga mampu menimbulkan daya pikat penonton (Smith terjemahan Suharto, 1985: 72). Klimaks merupakan suatu puncak dari sebuah tarian. Gerakan klimaks pada tarian ini terdapat pada ragam gerak Pakai Bedak, Pakai Alis, Pakai Lipstik, Sisir Rambut atau Gelungke Rambut dengan level rendah dan posisi penari duduk di lantai. Di dalam Tari Putri Berias secara keseluruhan ragam gerak pada klimaks untuk mempermudah penonton untuk memahami maksud dan ide yang ingin disampaikan oleh koreografernya.

\section{SIMPULAN}

Tari Putri Berias merupakan Tari Tradisional Kota Lubuklinggau, tari ini mengandung makna bagaimana seorang gadis menyiapkan diri dengan kepandaian serta keterampilan untuk nantinya sebagai bekal di masyarakat dan juga jangan sampai menjadi gunjingan, yang artinya ialah umpatan atau buah bibir, umpatan yang dimaksud bukan bermaksud umpatan yang tidak bagus tetapi sebaliknya umpatan disini merupakan perkataan yang bagus karena setiap warga menyampaikan dengan warga yang lain, bahwa disatu daerah itu ada seorang putri yang sangat cantik dan pandai menari, dari perkataan satu warga maka sampailah ke telinga warga yang lain bahkan sudah tersebar ke mana-mana dan menjadi bahan umpatan setiap warga dan membuat penasaran bagi yang mengetahuinya. Tari ini ditarikan dengan jumlah yang ganjil yang terdiri dari perempuan semua, karena pada tari ini gerak yang yang digunakan adalah gerakan layaknya seorang wanita yang sedang mempercantik diri atau berias.

Tari Putri Berias ditarikan oleh 5 orang penari perempuan yang berperan sebagai para gadis yang sedang berdandan. Tari Putri Berias diteruskan oleh pelatih tari di Sanggar Studio Lingga yaitu Sapda Jaya, S.Pd dan juga selalu dikembangkan dan selalu dijaga oleh pemerintah kebudayaan agar tetap selalu terjaga dan selalu dikenal oleh masyarakat Lubuklinggau khususnya para generasi, yang belum mengetahui makna yang terdapat dalam tarian ini. Di dalam tari ini terdapat pencipta beberapa unsur yang ada antara lain unsur gerak, unsur ruang, dan unsur waktu.

\section{DAFTAR PUSTAKA}

Dinas parawisata, 2015. Data base kebudayaan. Lubuklinggau: Disbudpar

Dharsono. 2007. Kritik Seni. Bandung: Rekayasa Sains

Hadi, Y Sumandiyo. 2007. Kajian teks dan konteks. ISI yogyakarta: Pustaka Book Publisher 
Pujleksono, Sugeng. 2015. Pengantar Antropologi Memahami Realitas Sosial Budaya Malang : Intrans Publishing.

Pika. 2015. Bentuk Penyajian Tari Nugal Di Sanggar Cahaya Bumi Nusantara Tebing Tinggi Empat Lawang. Palembang: Universitas PGRI Palembang (skripsi)

Rochayati, Rully.2014. Pengantar Dasar Komposisi Tari. Palembang: Titik Awal

Sugiyono. 2013. Metode Penelitian Pendidikan Pendekatan Kuantitatif, Kualitatif, dan R\&D. Bandung: Alfa Beta.

Sartono. 2007. Bahan Ajar Pengantar Pengetahuan Kesenian. Palembang: Universitas PGRI Palembang

Smith, Jacqueline. 1995. Komposisi Tari Sebuah Petunjuk Praktis Bagi Guru Yogyakarta: Ikalasti Yogyakarta.

Wahyudiyanto. 2008. Pengetahuan Tari. Surakarta: Rineka Cipta

Zuriah, Nurul. 2005. Metodologi Penelitian Sosial Dan Pendidikan. Malang: Bumi Aksar 